\section{The renal effects of dopamine and dobutamine in stable chronic heart failure}

Sir,

Among the observations made by Good and colleagues ${ }^{1}$ was the generalization that angiotensin converting enzyme inhibitors usually blunt the diuretic response to frusemide. Whilst it is true that the beneficial effects of these drugs on cardiac performance ${ }^{2}$ could be offset by renal deterioration, and, hence, impaired diuresis, due to drug-mediated hypotension ${ }^{3}$ or co-prescription of excessive doses of frusemide, ${ }^{4}$ there must be some patients in whom careful drug titration ${ }^{5}$ strikes the right balance between the beneficial effects on natriuresis ${ }^{6}$ and the adverse effects on glomerular filtration rate. The consequence could be a stabilization in diuretic requirements or even a diuretic sparing effect, as shown by some of the patients reported by Dzau et al. ${ }^{7}$ and by Odemuyiwa $e t$ $a l .{ }^{8}$ These beneficial effects may be obscured by the dosing schedules employed in double-blind trials of angiotensin converting enzyme inhibitors.

O.M.P. Jolobe Department of Geriatric Medicine, Tameside General Hospital, Fountain Street, Ashton-under-Lyne, Lancs OL6 9RW, UK.

\section{References}

1. Good, J., Frost, G., Oakley, C.M. et al. The renal effects of dopamine and dobutamine in stable chronic heart failure. Postgrad Med J 1992, 68 (Suppl 2): S7-S11.

2. Konstam, M.A., Rousseau, M.F., Kronenberg, M.W. et al. Effects of the angiotensin converting enzyme inhibitor enalapril on the long-term progression of left ventricular dysfunction in patients with heart failure. Circulation 1992, 86: 431-438.

3. Ljungman, S., Kjekshus, J., Swedberg, K. et al. Renal function in severe congestive heart failure during treatment with enalapril. Am J Cardiol 1992, 70: 479-487.

4. Parker, M., Lee, W.H., Medina, N. et al. Functional renal insufficiency during long term therapy with captopril and enalapril in severe chronic heart failure. Ann Intern Med 1987, 106: 346-354.

5. Dickstein, K. Practical guidelines for the use of converting enzyme inhibitors in congestive heart failure. Int $J$ Cardiol 1987, 15: 1-5.

6. Creager, M.A., Halperin, J.K., Bernard, D.B. et al. Acute regional circulatory and renal hemodynamic effects of converting enzyme inhibition in patients with congestive heart failure. Circulation 1981, 64: 483-489.

7. Dzau, V.J., Colucci, W.S., Williams, G.H. et al. Sustained effectiveness of converting enzyme inhibition in patients with severe congestive heart failure. $N$ Engl J Med 1980, 302: 1373-1379.

8. Odemuyiwa, O., Gilmartin, J., Kenny, D. et al. Captopril and diuretic requirements in moderate and severe chronic heart failure. Eur Heart J 1989, 10: 586-590.

\section{Addisonian crisis presenting with a normal short tetracosactrin stimulation test}

Sir,

The case reported by Butcher et al. ${ }^{1}$ draws attention to the fact that patients with Addison's disease may present rarely with predominant mineralocorticoid deficiency preceding critical loss of glucocorticoid reserve in evolving adrenal failure. They may be clinically Addisonian, but with serum cortisol concentrations lying within the normal range. There has been some dispute about what constitutes a normal response to Synacthen, ${ }^{2}$ although we have attempted to define the correct range in a prospective series of 50 patients admitted acutely to hospital. ${ }^{3}$ In this study we suggested a normal basal cortisol concentration of $250 \mathrm{nmol} / \mathrm{l}$, and a 30 minute peak of $>600 \mathrm{nmol} / 1$. The case reported by Butcher $e t$ al. fulfilled these criteria even though the peak serum cortisol response was assessed at 60 , rather than at 30 minutes. Nevertheless it seems that the patient's glucocorticoid reserve was essentially normal at presentation, while his aldosterone concentration was low. This has been previously reported ${ }^{4}$ and we also have managed a similar case.

The patient was a 25 year old motor mechanic who had been previously well. He presented as an emergency with a 9 day history of weakness and intermittent collapse. On examination lying/sitting blood pressures were $130 / 80$ and $110 / 90 \mathrm{mmHg}$, respectively. Serum sodium was $108 \mathrm{mmol} / 1$, potassium $6.8 \mathrm{mmol} / 1$ and urea $11.9 \mathrm{mmol} / \mathrm{l}$. Even though he was not pigmented, Addisonian crisis was suspected and a short Synacthen test was carried out, subsequently showing a basal 9 a.m. cortisol of $110 \mathrm{nmol} / \mathrm{l}$ and peak 30 minute cortisol of $720 \mathrm{nmol} / \mathrm{l}$.

He was rehydrated and started on hydrocortisone and fludrocortisone with good effect. In view of the normal response to Synacthen, corticosteroids were stopped for 24 hours and the short Synacthen test was repeated (5 days following the initial test). On this occasion the basal 9 a.m. cortisol was $150 \mathrm{nmol} / 1$ and peak 30 minute cortisol $170 \mathrm{nmol} / 1$. Plasma ACTH on an admission sample was $220 \mathrm{ng} / \mathrm{l}$ (upper limit of normal 120). Plasma renin concentration (overnight recumbent) was grossly elevated at $510 \mathrm{ng} / \mathrm{ml} /$ hour $(1-4.5)$ with a relatively low serum aldosterone concentration of $0.83 \mathrm{nmol} / 1(0-$ $5.5 \mathrm{nmol} / \mathrm{l})$. Adrenal antibodies were positive. He remains well on full corticosteroid replacement therapy since that time.

These cases emphasize the need to interpret the results of the short Synacthen test in the light of the clinical presentation. It remains, however, a simple and extremely robust test, and generally has high sensitivity.

S. Patel
C. Selby
T.L. Dornan'
W.J. Jeffcoate
City Hospital,
Chartment of Endocrinology and Clinical Chemistry
Nottingham, NG5 4DD and
'Department of Medicine,
Hope Hospital,
Salford M6 H8D, UK.

References

1. Butcher, G.P., Zambon, M., Moss, S. \& Walters, J.F. Addisonian crisis presenting with a normal short tetracosactrin stimulation test. Postgrad Med J 1992, 68: 465-466

2. Clayton, R.N. Diagnosis of adrenal insufficiency. $\mathrm{Br}$ Med $J$ 1989, 298: 271-272.

3. Patel, S., Selby, C. \& Jeffcoat, W.J. The short Synacthen test in acute hospital admissions. Clin Endocrinol 1991, 35: 259-261.

4. Park, G.R. \& Raggatt, P. Diagnosis of adrenal insufficiency. Br Med J 1989, 298: 670. 